\title{
Linking exogenous foliar application of glycine betaine and stomatal characteristics with salinity stress tolerance in cotton (Gossypium hirsutum L.) seedlings
}

Abdoul Kader Mounkaila Hamani 1,2, Shuang Li ${ }^{1,2}$, Jinsai Chen ${ }^{1,2}$, Abubakar Sunusi Amin 1,2, Guangshuai Wang ${ }^{1}$, Shen Xiaojun ${ }^{1}$, Muhammad Zain ${ }^{1,2}$ and Yang Gao ${ }^{1 *}$

\begin{abstract}
Background: Glycine betaine (GB) plays a crucial role in plants responding to abiotic stresses. Studying the physiological response of cotton seedlings to exogenous GB under salt stress provides a reference for the application of GB to improve the resistance of cotton seedlings under salt stress. The purpose of this research is to examine the impacts of foliar-applied GB on leaf stomatal structure and characteristics, gas exchange and chlorophyll fluorescence characteristics and plant growth indicators of Gossypium hirsutum L. under $\mathrm{NaCl}$ stress conditions.

Results: Under the salinity of $150 \mathrm{mM}$, the four concentrations of $\mathrm{GB}$ are $0,2.5,5$, and $7.5 \mathrm{mM}$, and the control (CK) was GB-untreated non-saline. Salt stress negatively affected leaf stomata as well as gas exchange and chlorophyll fluorescence and decreased plant growth parameters of cotton seedlings. The treatment with $5 \mathrm{mM}$ GB significantly increased the evolution of photosynthetic rate $\left(P_{n}\right)$, transpiration rate $\left(T_{r}\right)$, intracellular $\mathrm{CO}_{2}$ concentration $\left(C_{i}\right)$ and stomatal conductance $\left(g_{s}\right)$ compared to the GB-untreated saline treatment. The Exogenous foliar-applied GB has sustainably decreased the carboxylation efficiency $\left(P_{n} / C_{i}\right)$ and water use efficiency (WUE). The concentration of 5 $\mathrm{mM}$ GB leads to a significant improvement of leaf stomatal characteristics. The leaf gas exchange attributes correlated positively with stomatal density (SD), stomatal length (SL) and stomatal with (SW).

(Continued on next page)
\end{abstract}

\footnotetext{
* Correspondence: gaoyang@caas.cn

${ }^{1}$ Farmland Irrigation Research Institute, Chinese Academy of Agriculture Sciences/Key Laboratory of Crop Water Use and Regulation, Ministry of Agriculture and Rural Affairs, Xinxiang, Henan 453002, People's Republic of China

Full list of author information is available at the end of the article
}

(c) The Author(s). 2021 Open Access This article is licensed under a Creative Commons Attribution 4.0 International License, which permits use, sharing, adaptation, distribution and reproduction in any medium or format, as long as you give appropriate credit to the original author(s) and the source, provide a link to the Creative Commons licence, and indicate if changes were made. The images or other third party material in this article are included in the article's Creative Commons licence, unless indicated otherwise in a credit line to the material. If material is not included in the article's Creative Commons licence and your intended use is not permitted by statutory regulation or exceeds the permitted use, you will need to obtain permission directly from the copyright holder. To view a copy of this licence, visit http://creativecommons.org/licenses/by/4.0/. The Creative Commons Public Domain Dedication waiver (http://creativecommons.org/publicdomain/zero/1.0/) applies to the data made available in this article, unless otherwise stated in a credit line to the data. 
(Continued from previous page)

Conclusion: The overall results suggested that exogenous foliar supplementation with GB can effectively alleviate the damage of salt stress to cotton seedlings. The effect of applying $5 \mathrm{mM} \mathrm{GB}$ could be an optional choice for protecting cotton seedlings from $\mathrm{NaCl}$ stress through promoting the stomatal functions, photosynthetic activities and growth characteristics.

Keywords: Chlorophyll fluorescence, Cotton, Glycine betaine, Photosynthesis; salinity, Stomata

\section{Background}

Plants often faced several environmental stresses that badly results in decreased plant growth and productivity [1]. Salinity has become a severe problem of agriculture, which is restricting crop productivity worldwide. It is estimated that about $50 \%$ of land loss will be observed globally due to the destructive effects of soil salinization by Wang et al. [2]. Generally, when soluble salts increased, they induced three kinds of threats to plants by creating hurdles for roots to take water in, like drought (osmotic effect), ion toxicity, and antagonistic effects of saline solutions. Salinity disturbs the energy and lipid metabolism, photosynthesis, and protein synthesis leading to stunted growth, wilting, or ultimately, death [3, 4]. Successful adaptation to salinity stress relies on many physiological variations [5]. Usually, plants build up some mechanisms to endure salts' existence within cells or to exclude if from their cells. How crops respond to salt stress and how productive their strategies are varied among the different species [6].

Many kinds of osmolytes, including amino acids, soluble sugars, proline, and GB are produced by salt-resistant plants in an excess amount to adjust the salinity [7]. This osmotic regulation sustains sub-cellular structures and diminishes the oxidative injures because of ROS-induced elevated salinity stress [8]. Endogenously biosynthesis of GB is known as a response to stresses. The extent of biosynthesized GB mostly relies on the degree of salinity resistance [9]. The plants that are not capable of $\mathrm{GB}$ accumulation can resist salinity by exogenous foliar supplementation with GB [10,11]. Further studies are required to clear the current controversy about GB function in resistance to salinity stress. Possibly, the role of the said osmolyte is based on the studied species and varieties.

One interesting feature of GB-mediated plant resilience to environmental stresses is the competence of $\mathrm{GB}$ produced in chloroplast to defend the photosynthetic apparatus by protecting the lipids and enzymes that are essential to sustain the optimum and linear electron flow via thylakoid membranes and sustain $\mathrm{CO}_{2}$ absorbance as well [12, 13]. Furthermore, an important and defensive function of GB inside the chloroplasts is photosystem II (PSII) stability, which remained the most susceptible compound of photosynthetic apparatus, also suggested to have a vital function in plants photosynthetic response to different environmental constraints [14]. Many researchers have reported stabilizing and protecting foliar-applied GB on the non-activation of PSII complex due to stress [10]. Previous investigations to correlate stomatal conductance ( $g \mathrm{~s}$ ) and salt tolerance in barley have found positive relationships between yield and gs under salinity stress conditions [15]; Similar observations were made in various plant species [16]. However, changes in stomatal pore aperture or altered stomatal density (SD) could result in variations in gs. E Brugnoli and $M$ Lauteri [16] reported that under high saline condition and changes in SD, plants can use a fundamental mechanism to optimse water use efficiency, as reducing the SD would be beneficial to plants subjected to osmotically stress. However, to the higher of our knowledge no study has linked $\mathrm{NaCl}$ stress-induced changes in SD with salinity tolerance in cotton seedlings using exogenous foliar supplementation of GB.

Cotton is one of Gossypium species considered to be of a global agricultural importance [17]. In northwest China and Central Asia, cotton production is limited by salinity stress caused by secondary soil salinization. However, still scarce information is available on exogenous supplementation with GB to cotton plants under saline conditions. Therefore, concidering the importance of compatible osmolyte and its action as an osmoprotectant in plants under salinity stress. This study is designed to figure out the effects of exogenous foliarapplied GB at different concentrations on the stomatal response of one cotton genotype irrigated with saline water. The current study could contribute to better understand the roles of exogenous sprayed GB on cotton seedlings stomatal functions under salinity stress.

\section{Results}

Effects of foliar-applied GB on gas exchange evolution and chlorophyll fluorescence

After 10 days of $150 \mathrm{mM} \mathrm{NaCl}$ treatment, salinity significantly reduced the cotton leaf photosynthesis parameters, including $P_{r}, C_{\dot{v}} g_{s}$, and $T_{r}$, which significantly decreased (Fig. 1a, b, c, d), compared to CK. $P_{n}, T_{r}$, and $g_{s}$ in the GBtreated saline treatments, mainly $(5 \mathrm{mMGB})$ were significantly higher than in GB-untreated saline treatment after initially being applied GB for 10 days. Instantaneous 
(a)

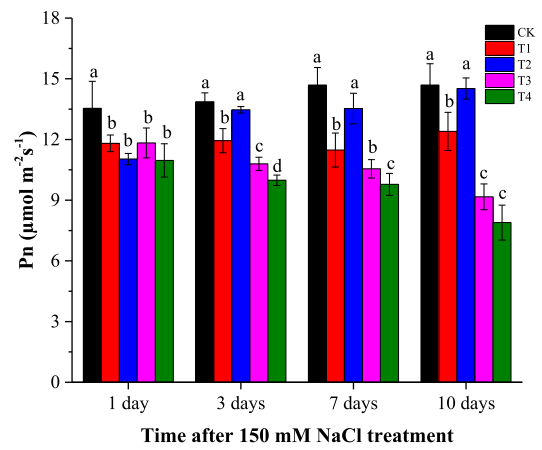

(c)

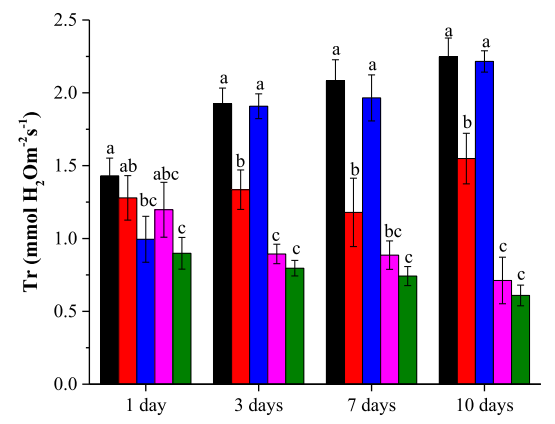

(e)

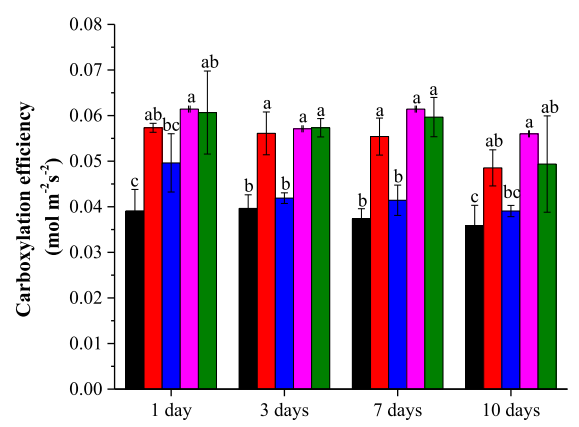

(b)

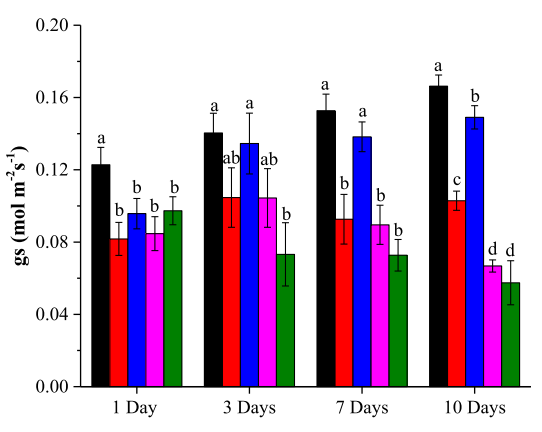

(d)

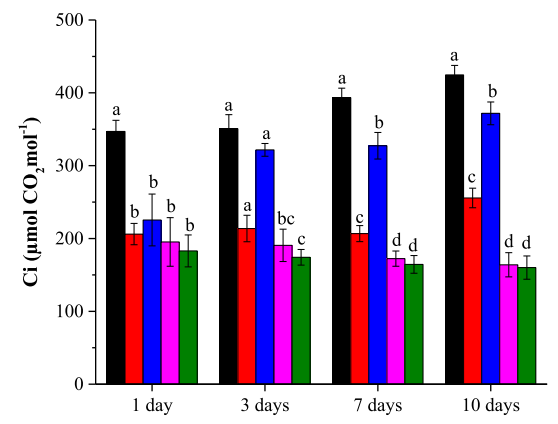

(f)

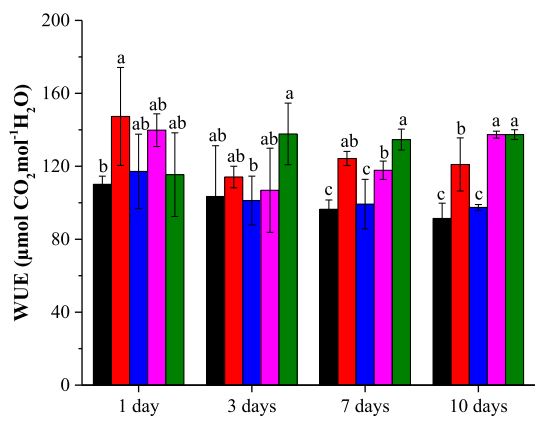

Fig. 1 Effect of foliar-applied GB on salt-stressed cotton seedlings $P_{n,} g_{s,} T_{n}, C_{i}$ Carboxylation efficiency $\left(P_{n} / C_{i j}\right)$ and $W U E\left(P_{n} / g_{s}\right)$ are a, b, $C, d, e$ and f respectively. $\mathrm{CK}=$ control; $\mathrm{T} 1=2.5 \mathrm{mM} \mathrm{GB} ; \mathrm{T} 2=5 \mathrm{mM} \mathrm{GB} ; \mathrm{T} 3=7.5 \mathrm{mM} \mathrm{GB}$ and $\mathrm{T} 4=150 \mathrm{mM} \mathrm{NaCl}$. Data are Mean \pm standard deviation $(n=3)$. Different alphabets on top of error bars represent significant differences $(p<0.05)$

Table 1 The chlorophyll fluorescence parameters in the different treatments

\begin{tabular}{lllllll}
\hline Treatment & $\boldsymbol{\Delta} \boldsymbol{F} / F_{m}^{\prime}$ & $\boldsymbol{\Phi}_{\boldsymbol{P S I I}}$ & $\boldsymbol{F v} / \boldsymbol{F m}$ & $\boldsymbol{q N}$ & $\boldsymbol{q P}$ & $\boldsymbol{N P Q}$ \\
\hline CK & $0.747 \pm 0.006 \mathrm{a}$ & $0.352 \pm 0.015 \mathrm{a}$ & $0.828 \pm 0.003 \mathrm{a}$ & $0.765 \pm 0.019 \mathrm{ab}$ & $0.459 \pm 0.058 \mathrm{~b}$ & $1.726 \pm 0.128 \mathrm{bc}$ \\
T1 & $0.715 \pm 0.027 \mathrm{ab}$ & $0.271 \pm 0.015 \mathrm{bc}$ & $0.825 \pm 0.007 \mathrm{a}$ & $0.739 \pm 0.007 \mathrm{~b}$ & $0.496 \pm 0.019 \mathrm{~b}$ & $1.554 \pm 0.079 \mathrm{c}$ \\
$\mathrm{T} 2$ & $0.730 \pm 0.005 \mathrm{a}$ & $0.310 \pm 0.015 \mathrm{ab}$ & $0.829 \pm 0.004 \mathrm{a}$ & $0.732 \pm 0.017 \mathrm{~b}$ & $0.490 \pm 0.026 \mathrm{~b}$ & $1.538 \pm 0.087 \mathrm{c}$ \\
$\mathrm{T} 3$ & $0.707 \pm 0.012 \mathrm{~b}$ & $0.257 \pm 0.023 \mathrm{c}$ & $0.801 \pm 0.015 \mathrm{ab}$ & $0.777 \pm 0.017 \mathrm{ab}$ & $0.536 \pm 0.046 \mathrm{ab}$ & $1.748 \pm 0.096 \mathrm{bc}$ \\
T4 & $0.698 \pm 0.005 \mathrm{~b}$ & $0.239 \pm 0.027 \mathrm{c}$ & $0.786 \pm 0.017 \mathrm{~b}$ & $0.824 \pm 0.042 \mathrm{a}$ & $0.559 \pm 0.033 \mathrm{a}$ & $2.260 \pm 0.419 \mathrm{a}$ \\
\hline
\end{tabular}

Note: $\Delta F / F_{m}^{\prime}=$ Effective quantum efficiency of photosystem II, $\Phi_{P S I I}=$ Actual photochemical efficiency of photosystem II, $F v / F m=$ Maximal photochemical efficiency of photosystem II, $q N=$ non-photochemical quenching, $q P=$ photochemical quenching of variable chlorophyll, $N P Q=$ non-photochemical quenching Data are Mean \pm standard deviation $(n=3)$. CK $=$ control; $\mathrm{T} 1=2.5 \mathrm{mM} \mathrm{GB} ; \mathrm{T} 2=5 \mathrm{mM} \mathrm{GB} ; \mathrm{T} 3=7.5 \mathrm{mM} \mathrm{GB}$ and T4 $=150 \mathrm{mM} \mathrm{NaCl}$. Different alphabets in each subcolumn represent significant differences $(p<0.05)$ 
carboxylation efficiency $\left(P_{n} / C_{i}\right)$ and water use efficiency (WUE) were sustainably decreased during the 10 days of $150 \mathrm{mM}$ saline water treatment when compared the GBuntreated non-saline to the GB-untreated saline treatments (Fig. 1e, f). From the 3rd day to 10th day of exogenous foliar treatment with GB under saline condition, the concentration of $5 \mathrm{mM} \mathrm{GB}$ was more effective in decreasing instantaneous $P_{n} / C_{i}$ and WUE.

The chlorophyll fluorescence parameters showed significant differences among the different treatments due to the foliar application of three different levels of $\mathrm{GB}$ under salt stress (Table 1). $F_{v} / F_{m}, \Phi_{P S I I}[18]$, and $\Delta F / F_{m}^{\prime}$ had a similar trend, which decreased sustainably by 6.56 , 5.07 and $32.1 \%$, respectively, under $150 \mathrm{mM}$ salinity alone compared to $\mathrm{CK}$, all of them significantly increased with the foliar supplementation with $5 \mathrm{mMGB}$ (Table 1$)$. Only the value of $F_{v} / F_{m}$ in T4 (0.786) was less than 0.80 with a significant difference with $\mathrm{CK}, \mathrm{T} 1$ and $\mathrm{T} 2$, suspecting that photo-inhibition might have occurred in T4 [18]. More significant differences among treatments were observed for $\Delta F / F_{m}^{\prime}$ than for $F_{v} / F_{m}$.

The $q P, q N$, and $N P Q$ showed a contrary trend with $F_{v} /$ $F_{m}, \Delta F / F_{m}^{\prime}$ and $\Phi_{P S I I}$, they were sustainably higher in the GB-untreated saline treatment (T4) compared to the wellwatered control, but all of them significantly decreased in $\mathrm{T} 1$ and T2 due to the foliar application of GB (Table 1). The differences in $q N$ and $q P$ between the GB-treated saline treatments were insignificant (Table 1). The differences in NPQ between control and GB-treated saline treatments were insignificant, but all the treatments, when compared to the saline treatment alone, showed significant differences. The NPQ showed a maximum value of 2.260 in T4.

\section{Effects of foliar-applied GB on stomatal structure and characteristics}

Figure 2 showed the effect of different exogenously applied GB concentrations on seedlings stomatal structure under $150 \mathrm{mM}$ salt stress. Under the condition of $\mathrm{NaCl}$ alone without exogenous treatment (T4), the small pores on the surface of leaves (stomatal) are more closed compared to that on the control treatments' leaves. The foliar supplementation with 2.5 and $5 \mathrm{mMGB}$ increased the opening diameter of stomata under salt stress when compared to the non-exogenously treated saline (Fig. 2). Salinity has significantly decreased stomatal characteristics including, stomatal density, length and width when compared CK to the exogenously untreated saline treatment (Fig. 3). Among all the foliar-applied GB levels, only the concentration of $5 \mathrm{mM} \mathrm{GB}$ has significantly increased the stomatal length and width under salt stress condition (Fig. $3 \mathrm{~b}, \mathrm{c})$. But, none of the exogenous GB levels had a significant positive effect on leaf stomatal density (Fig. 3a).

\section{Effects of foliar-applied GB on the evolution of growth parameters}

During the 10 days of salt treatment, plant growth characteristics such as LWP and leaf area were significantly decreased comparing the well-watered treatment with the GB-treated saline treatments (Fig. 4). Up to 10 days of exogenous foliar supplementation with $G B$, the value
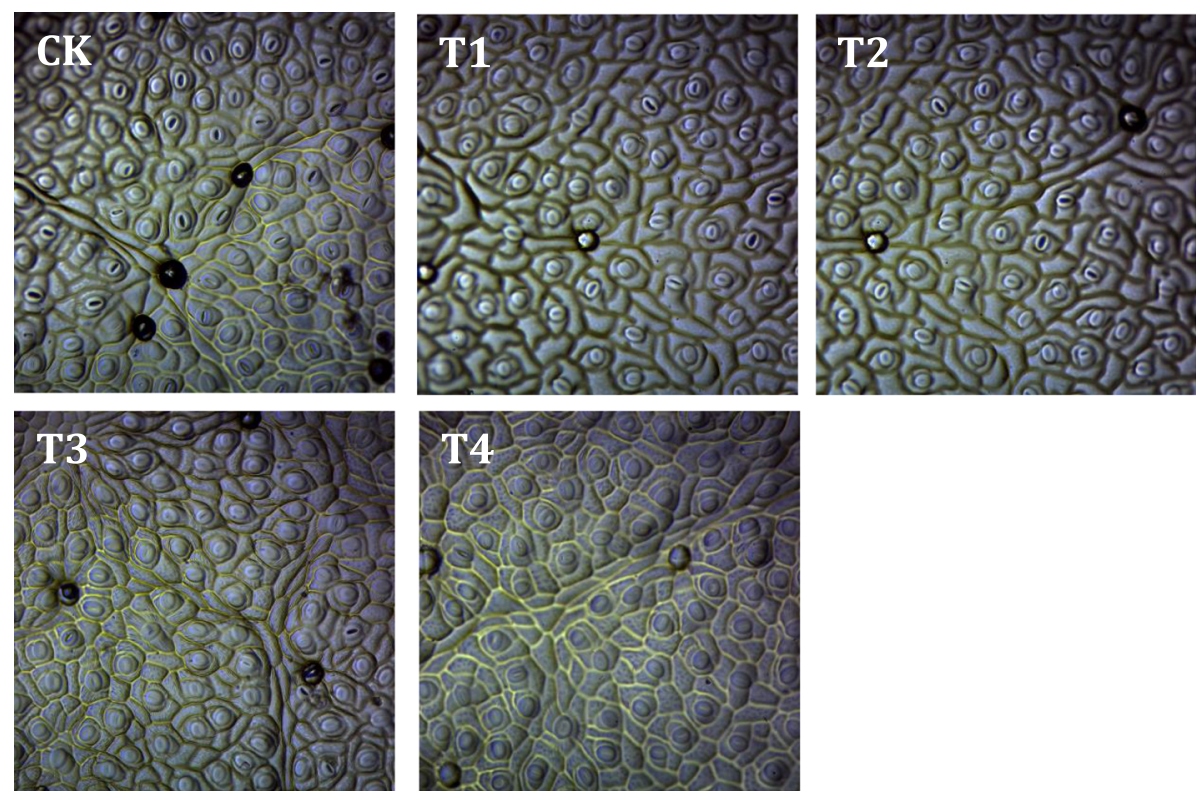

Fig. 2 Effect of foliar-applied GB on stomatal morphology of salt-stressed cotton seedlings. CK= control; T1 = 2.5 mM GB; T2=5 mM GB; T3=7.5 $\mathrm{mM} \mathrm{GB}$ and $\mathrm{T} 4=150 \mathrm{mM} \mathrm{NaCl}$ 

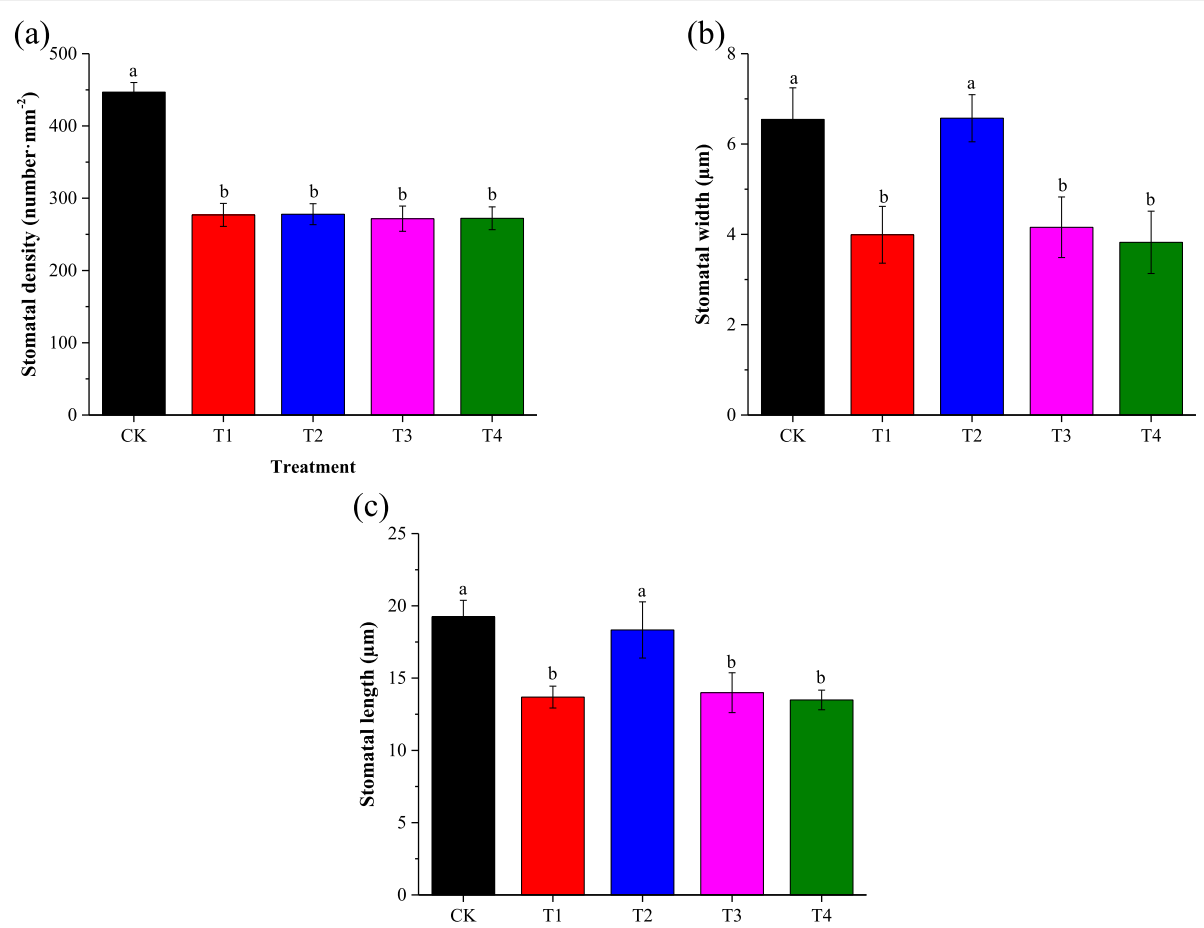

Fig. 3 Effect of foliar-applied GB on salt-stressed cotton seedlings stomatal density, stomatal width, and stomatal length are $a$, b, and c respectively. $\mathrm{CK}=$ control; $\mathrm{T} 1=2.5 \mathrm{mM} \mathrm{GB} ; \mathrm{T} 2=5 \mathrm{mM} \mathrm{GB} ; \mathrm{T} 3=7.5 \mathrm{mM} \mathrm{GB}$ and $\mathrm{T} 4=150 \mathrm{mM} \mathrm{NaCl}$. Data are Mean \pm standard deviation $(n=3)$. Different alphabets on top of error bars represent significant differences $(p<0.05)$

of LWP remained significantly lower in the GB-treated saline treatments (Fig. 4a). Only the treatment with 5 Mm GB had a significant positive effect on leaf area at the 10th day of treatment GB foliar treatment under salt stress (Fig. 4b).

Effects of foliar-applied GB on GB, proline, soluble sugar, and protein content

$\mathrm{GB}$, proline, soluble sugar and protein content measured in cotton leaves after harvesting are presented in Fig. 5.
The endogenous concentrations of GB [18] and proline were significantly increased as response to salt stress. While the soluble suger content was dramaticaly decreased under saline condition when compared the saltstressed alone with control. Exogenous foliar suplementation with GB has significantly increased the endogenous GB content (Fig. 5a) and decreased proline content (Fig. 5b) when compared the exogenous foliar treatments with the salt-stressed alone. The soluble suger concentration was insignificantly affected by the
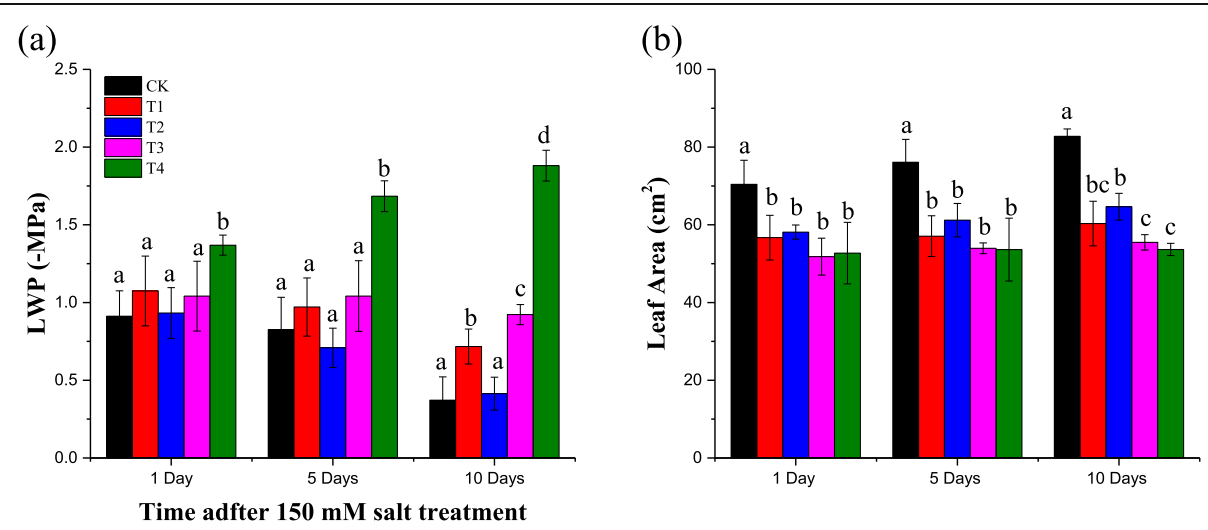

Fig. 4 Effect of foliar-applied GB on salt-stressed cotton seedlings LWP and leaf area are a and b, respectively. CK= control; $T 1=2.5 \mathrm{mM} G B$; $T 2=$ $5 \mathrm{mM} \mathrm{GB} ; \mathrm{T} 3=7.5 \mathrm{mM} \mathrm{GB}$ and T4 $=150 \mathrm{mM} \mathrm{NaCl}$. Data are Mean \pm standard deviation $(n=3)$. Different alphabets on top of error bars represent significant differences $(p<0.05)$ 
(a)

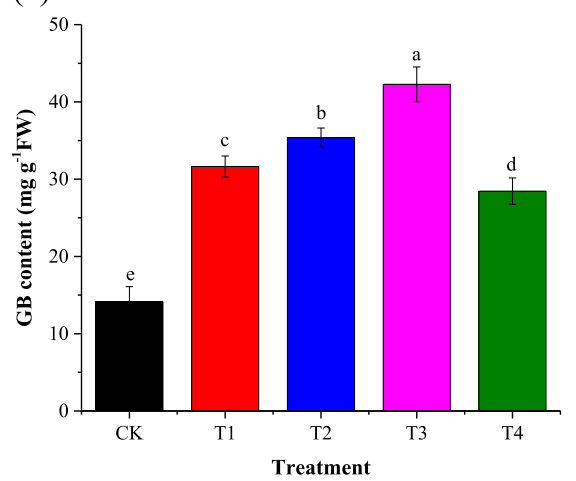

(c)

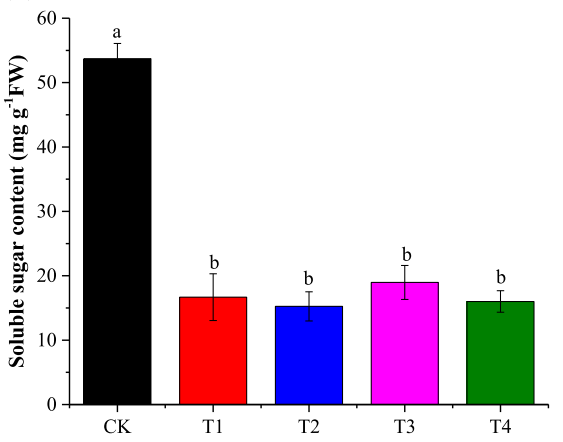

(b)

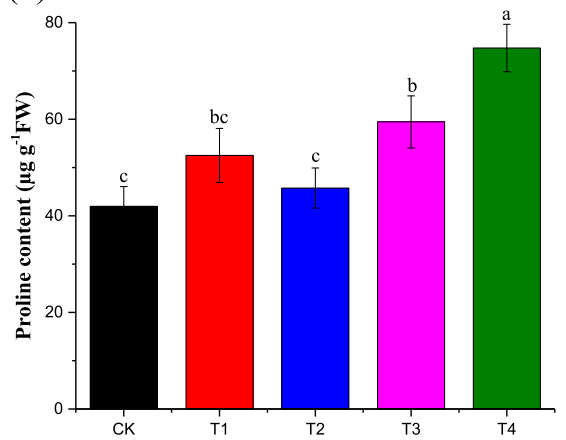

(d)

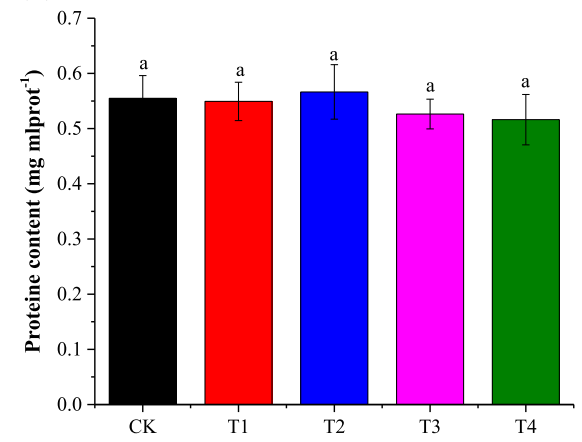

Fig. 5 Effect of foliar-applied GB on salt-stressed cotton seedlings GB content, proline content, soluble sugar content, and protein content are a, b, $c$ and d respectively. CK= control; T1 = 2.5 mM GB; T2 $=5 \mathrm{mM} \mathrm{GB} ; \mathrm{T} 3=7.5 \mathrm{mM} \mathrm{GB}$ and T4 $=150 \mathrm{mM} \mathrm{NaCl}$. Data are Mean \pm standard deviation $(n=3)$. Different alphabets on top of error bars represent significant differences $(p<0.05)$

exogenously-applied GB (Fig. 5c). Treatment with 150 $\mathrm{mM}$ salt without exogenous and treatment with exogenous GB under $150 \mathrm{mM}$ salt stress had an insignificant effect on protein content(Fig. 5d). Differences in protein content in cotton leaves of all treatments were insignificant.

\section{Relationship of endogenous GB content and gas} exchange parameters with stomatal characteristics

Cotton seedlings leaf gas exchange parameters were negatively affected by salinity, but GB leads a significant

Table 2 Correlation matrix between gas exchange parameters and Stomatal characteristics

\begin{tabular}{|c|c|c|c|c|c|c|c|}
\hline & $P_{n}$ & $g_{s}$ & $C_{i}$ & $T_{r}$ & SL & SW & SD \\
\hline$P_{n}$ & & $96^{* * *}$ & $92^{* * *}$ & $99^{* * *}$ & $59^{* *}$ & $71^{* *}$ & $68^{* *}$ \\
\hline$g_{s}$ & & & $99^{* * *}$ & $95^{* * *}$ & $72^{* *}$ & $85^{* *}$ & $73^{* *}$ \\
\hline$C_{i}$ & & & & $95^{* * *}$ & $72^{* *}$ & $87^{* *}$ & $72^{* *}$ \\
\hline$T_{r}$ & & & & & $62^{* *}$ & $79^{* *}$ & $70^{* *}$ \\
\hline $\mathrm{SL}$ & & & & & & $65^{* *}$ & $56^{* *}$ \\
\hline SW & & & & & & & $89^{* * *}$ \\
\hline
\end{tabular}

Note. $P_{n}=$ Net photosynthetic rate, $g_{s}=$ stomatal conductance, $C_{i}=$ intracellular $\mathrm{CO}_{2}$ concentration, $T_{r}=$ Transpiration rate, $S D=$ Stomatal density, $S L=$ Stomatal length, $S W=$ stomatal width. ${ }^{*},{ }^{* *}$, and ${ }^{* * *}$ indicate significance levels of $P<$ $0.05, P<0.01$, and $P<0.001$ respectively improvement in cotton leaf gas exchange parameters when applied to leaves. High significant positive Persons' correlation was observed between leaf gas exchange parameters. Cotton seedlings leaf stomatal characteristics showed high significant positive correlated with gas exchange parameters (Table 2). All stomatal characteristis (SD, SL, and SW) showed siginificant positive relashioship with gs (Fig. 6). On another hand, the leaf endogenous concentration of GB significantly negativelly correlated with leaf stomatal density (SD), while there was no significant relashionship between GB content and stomatal length (SL) and stomatal wigth (SW) (Fig. 7).

\section{Discussion}

Exogenous foliar supplementation with compatible solutes is commonly known to trigger tolerance mechanism of plants against various abiotic stresses conditions. Exogenous foliar-applied GB can easily penetrate through leaves and be transferred to other parts of plants, where it would contribute to ameliorate plants resistance to stress conditions [19]. In the current study, we have investigated cotton seedlings' physiological response to short-time exogenous foliar treatment with GB under $150 \mathrm{mM}$ saline condition. In this connection, we mostly 

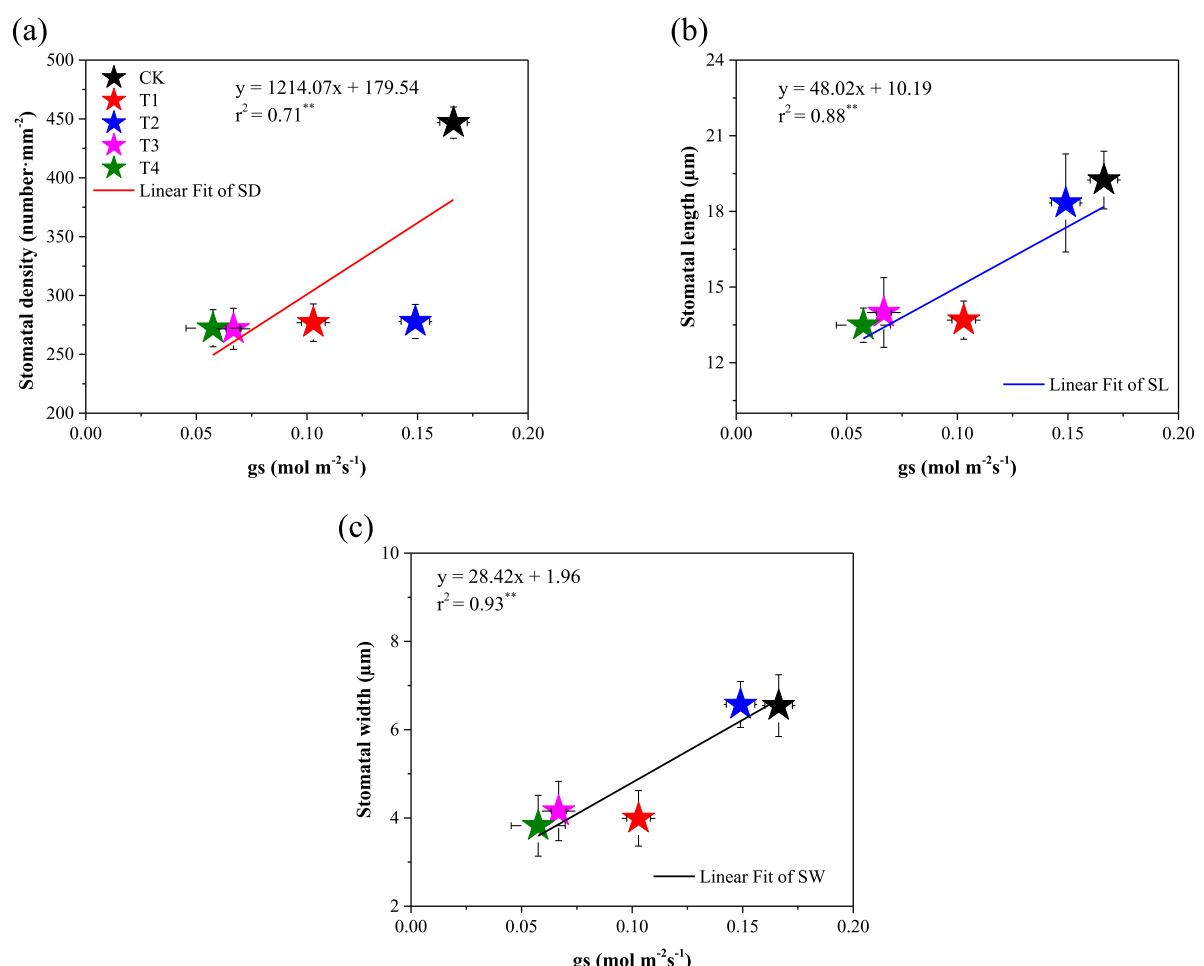

Fig. 6 Relationship between stomatal characteristics (a) stomatal density (SD), (b) stomatal length (SL) and (c) stomatal width (SW) and stomatal conductance (gs). $\mathrm{CK}=$ control; $\mathrm{T} 1=2.5 \mathrm{mM} \mathrm{GB} ; \mathrm{T} 2=5 \mathrm{mM} \mathrm{GB} ; \mathrm{T} 3=7.5 \mathrm{mM} \mathrm{GB}$ and $\mathrm{T} 4=150 \mathrm{mM} \mathrm{NaCl}$. Data are Mean \pm standard deviation $(n=3)$, ${ }^{*}$ and ${ }^{*}$ indicate significance levels of $P<0.05$ and $P<0.01$, respectively

focused on the effect of foliar-applied GB on seedlings' stomatal activity attributes under saline conditions. Studies involving plant response to saline conditions have been conducted using physiological, biochemical, molecular, and proteomic methods $[20,21]$. The alteration of some key physio-biochemical processes such as tissue water potential, photosynthetic, and chlorophylls efficiencies resulting from salt stress when harmonized with excessive production and the reactions of ROS leads to an increase in oxidative stress [22].

Plants' stomatal are the source of exchange of air and water between plant leaves and the atmosphere. Stomatal are also one of the main factors affecting the photosynthetic and transpiration process of plants. Plants can adjust stomatal distribution according to changes in environmental factors. Stomatal density and stomata size, make plants lose less water condition, get the most $\mathrm{CO}_{2}$ down [23]. Many factors involved in the relationship between plant water status and stomatal functionality [24]. Salt stress condition in this study has decreased the stomatal opening and density of cotton leaves. Similarly, a research reported that under saline conditions, plants have to close their stomata due to water loss [25].

Leaf gas exchange regulation is known to be an important aspect of improving plant resistance to various environmental stresses, including salt stress [18]. Salt stress is reputed to photosynthesis inhibition in many plant species as mentioned in researches that $T_{r}, P_{n}$, and $g_{s}$ decrease under saline conditions [26, 27]. Regulating leaf gas exchange capacity is vital for plants' resistance to various environmental and non-environmental stress conditions [28]. Reports showed that plants implement that strategy to regulate several photosynthetic attribute, including $C_{i}, T_{r}, P_{n}$, and $g_{s}[29,30]$. We hypothesized that the positive effect of $\mathrm{GB}$ on $g_{s}$ could simply be mechanical, as observed that GB increase the proportion of bound water in the cell structures as well as the turgor pressure in the guard cells of stomatal [31]. Moreover, we observed that foliar-applied GB increased $g_{s}$ and allows more efficient gas exchange. Exogenous foliar supplementation with GB was known to enhance growth, $P_{n}$, leaf water content, and PSII of salt-stressed maize plants [32]. In our study, we observed that $P_{n}, C_{i}$, $T_{r}$, and $g_{s}$ sustainably decreased under $150 \mathrm{mM}$ salinity stress (Fig. 1), but the foliar supplementation with GB statistically enhanced them under salt stress. As observed, the WUE and the carboxylation efficiency were sustainably increased as response $\mathrm{NaCl}$ treatment. The increase of WUE under150 mM salt condition could explain that cotton seedlings might utilize the water efficiently, in order to sustain the growth. In harmony with our findings, it was observed an increase in the WUE in 

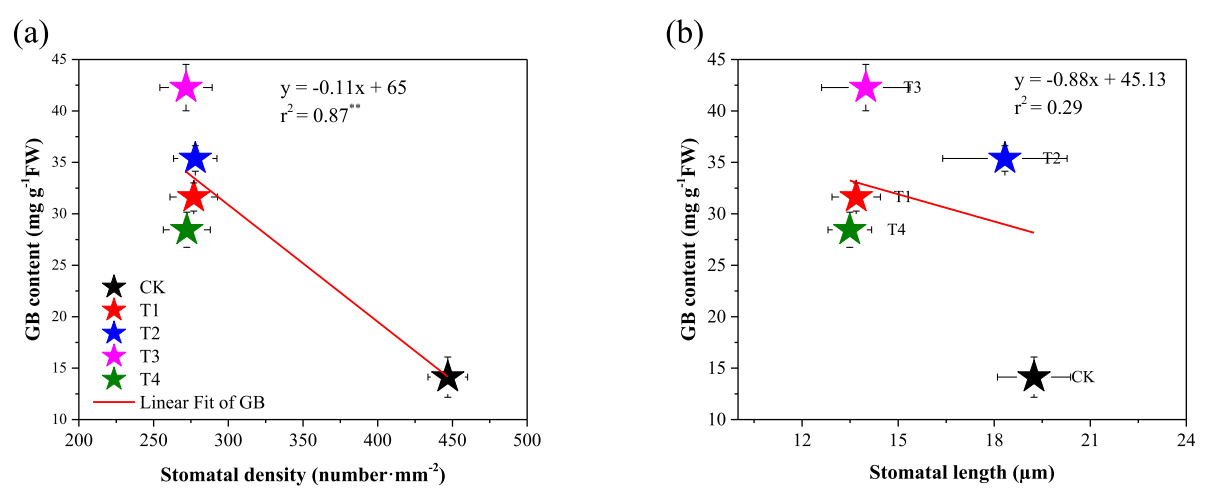

(c)

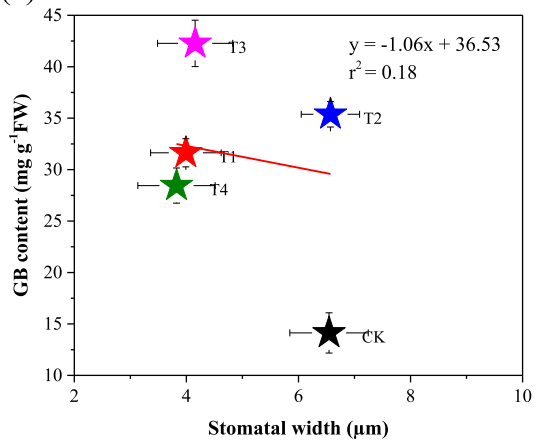

Fig. 7 Relationship between endogenous GB content and (a) stomatal density (SD), (b) stomatal length (SL) and (c) stomatal width (SW). CK= control; $\mathrm{T} 1=2.5 \mathrm{mM} \mathrm{GB} ; \mathrm{T} 2=5 \mathrm{mM} \mathrm{GB} ; \mathrm{T} 3=7.5 \mathrm{mM} \mathrm{GB}$ and T4 $=150 \mathrm{mM} \mathrm{NaCl}$. Data are Mean \pm standard deviation $(n=3)$, * and ${ }^{* *}$ indicate significance levels of $P<0.05$ and $P<0.01$, respectively

sugar beet under a moderate saline condition [33]. Furthermore, exogenous foliar application of GB improved growth, $P n$, and WUE in maize plants subjected to salt stress [32].

Leaf stomatal characteristics and gas exchange parameters negatively responded to the short-time stress of $150 \mathrm{mM} \mathrm{NaCl}$. The decrease of leaf gas exchange attributes might be attributed to stomatal restriction, including stomatal closure and stomatal density (SD) reduction. A recent study reported that, salt stress inhibits the photosynthetic process of plant leaves mainly including stomatal restriction [23]. As expected our study results showed a significant positive relationship between gas exchange attributes and stomatal characteristics (Table 2). Persons' correlation revealed a significant positive relationship between cotton leaf SD and leaf stomatal conductivity, reflecting that the variation of stomatal density directly affects the stomatal conductivity. In this study, we found the exogenous foliar application of GB to be a suitable way to improve cotton leafs stomatal opening (Fig. 2) which finally turns to improve gas exchange attributes (Fig. 2) under saline conditions. The current study showed that cotton leaf stomatal characteristics (SD, SL and SW) have significant positive relationships with $g s$ (Fig. 6). Furthermore the cotton leaf endogenous GB content correlated negatively with SD (Fig. 7), meaning that SD sustainably decreased with the $\mathrm{NaCl}$-induced $\mathrm{GB}$ accumulation.

Chlorophyll fluorescence is a key signal reflecting the plant growth inhibition by a saline environment. A suitable and rapid method for detecting and measuring plant resistance to abiotic stresses, is evaluating the integrity of leaf photosynthesis based on chlorophyll fluorescence [18]. When higher plants are subjected to salinity stress, $F_{v} / F_{m}$ of non-salt tolerant plants is reduced [34], but that of salt-resistant plants is enhanced [35]. In our study, saline conditions significantly decreased PSII activity [18] as also reported in radish [36], tomato [37], sunflower [38], and wheat [39]. But upon the application of GB, PSII activity was increased for the saline conditions [18]. Similar results were observed for eggplant [40], but opposite to the result obtained in watermelon [41]. Therefore, the reduction in $F_{v} / F_{m}$ can be considered as a symbol of photo-inhibition when plants are subjected to salinity. It is usually noticed that photo-inhibition results in a vast reduction in the actual quantum yield $\left(\Delta F / F_{m}^{\prime}\right)$, which response to salinity stress is similar to that of $F_{v} / F_{m}$ but more significantly. It has been reported that GB application do not affect PSII 
photochemistry $\left(F_{v} / F_{m}\right)$ maximum efficiency [19]. Enhancements in $g s$ and PSII is associated with the improvement in $P n$ of salt-stressed maize plants treated with GB. The $F_{v} / F_{m}$ remained approximately constant $(0.80 \sim 0.85)$ for various plant species growing in normal conditions [42]. In this study, only the $F_{v} / F_{m}$ of T4 (0.786 \pm 0.017$)$ was below 0.80 [18], meaning that it was inhibited more significantly by salinity than the other four treatments (Table 1). We concluded that the foliar application of GB significantly increased the $F_{v} / F_{m}$ of cotton under salt stress conditions.

Moreover, the decrease of $F_{v} / F_{m}$ is due to the improvement of $P n$ or heat dissipation, while the photosynthetic activity of plants can be computed by photochemical quenching $(q P)$ and the capacity of plants to dissipate excess light energy can be reflected by nonphotochemical quenching ( $q N$ or $N P Q$ ). In our study, the $q P, q N$, and $N P Q$ were higher in the GB-untreated saline treatment (Table 1). The foliar application of GB significantly decreased the values of $q P$ and $q N$ in $\mathrm{T} 1$ and $\mathrm{T} 2$ and that of $N P Q$ in $\mathrm{T} 1, \mathrm{~T} 2$, and $\mathrm{T} 3$, but for $q N$ the differences were insignificant between the GBtreated saline treatments and the GB-untreated saline treatment (Table 1). A study on maize showed a significant increase in NPQ under saline conditions. But, less increase was observed in NPQ in salt-stressed maize plants as response to exogenous foliar application of GB [32].

Accumulations of GB, proline, protein and soluble sugar have been determined in various plant species subjected to salinity stress. Salinity stress has most of the time increased the endogenous concentrations of GB in shoot of many plant, while, endogenous GB content insignificantly vary in root of many plants [43]. It was observed an increase of proline content in the rice salttolerant genotype with exogenous foliar application of GB under salt stress conditions [44]. On the contrary, foliar-applied GB reduced the proline content in S-24 salt-tolerant wheat and IR28 salt-sensitive rice and $\mathrm{MH}-$ 97 salt-sensitive genotypes under saline conditions [44, 45]. Similarly proline content was decreased in spinach and rapeseed as response to exogenously applied GB under saline conditions [46]. In our study, it was observed that $150 \mathrm{mM} \mathrm{NaCl}$ condition caused an increase of endogenous GB [18] and proline content and a decrease of soluble sugar content (Fig. 5). We hypothesized that the cotton genotype used in this experiment is able itself to synthesize a considerable amount of GB under saline conditions. However, exogenous foliar application of $\mathrm{GB}$ resulted in further increase in GB and soluble sugar content but decrease in proline concentration. In a harmony with our findings, earlier studies found exogenous foliar-applied GB to enhance soluble sugar content under saline conditions [47-49]. In contradiction with our results, exogenous foliar application of GB caused an increase in rice under saline conditions [44]. It has been reported that various plants species accumulate greater concentrations of protein under saline conditions [43]. In the current study, the accumulation of protein in cotton leaves was insignificantly affect by salinity.

\section{Conclusion}

GB has been widely used in agriculture as a compatible solute, which can usually improve abiotic stress tolerance in crops. Our results concluded that foliar supplementation with GB could be a suitable for improving the leaf stomatal structure and characteristics of cotton seedlings. This study demonstrated that under $\mathrm{NaCl}$ stress condition, the increase of stomatal characteristics by foliar supplementation with GB leads to a rapid improvement of gas exchange and chlorophyll fluorescence in Gossypium hirsutum L. seedlings. In summary, the improved salt tolerance by exogenous application of GB could be due to its contribution to significantly improve gas exchange parameters. The strategic and economic level of exogenous GB should be fixed for alleviating the adverse effect of $\mathrm{NaCl}$ stress on cotton. This study recommends foliar spraying of $5 \mathrm{mM} \mathrm{GB}$ for mitigating the $\mathrm{NaCl}$-induced damages in cotton seedlings by improving leaf stomatal responses to saline conditions. Thus, further studies should examine the biochemical and molecular mechanisms of foliar-applied GD and endogenously accumulated GB in order to find out the similarities and differences between endogenously synthesised and foliar-applied and GB.

\section{Methods}

\section{Plant materials}

The current research was conducted during 45 days from sowing to harvesting in a controlled environmental chamber at the Research site of Farmland Irrigation Research Institute, Graduate School of Chinese Academy of Agricultural Sciences (FIRI-GSCAAS), located in Qiliying, Xinxiang city, Henan Province, North China. The chamber conditions were as follows: the temperature for day/night of $30 / 20^{\circ} \mathrm{C}$, photoperiod of 14h [06:00-20:00 $\mathrm{h}$ Beijing Standard Time (BST)], the density photosynthetic photon flux was $350 \mu \mathrm{mol} \mathrm{m}^{-2} \mathrm{~s}^{-}$ ${ }^{1}$ and relative humidity in the range of $50-60 \%$. Uniform seeds of Gossypium hirsutum L., cultivar Xinluzhong-37, were obtained and disinfected in $0.3 \%$ hydrogen peroxide for $30 \mathrm{~min}$ and finally washed thrice with deionized water. To insure the germination, cotton seeds were sown in flat trays containing sterile sand, and one-weekold seedlings with uniform size were transplanted into plastic pots $(16 \mathrm{~cm}$ diameter, $18 \mathrm{~cm}$ height, and 1 plant pot $^{-1}$ ). Each pot was filled with $2.5 \mathrm{~kg}$ of sterilized sand in order to avoid any nutrient effect. The transplanted 
Table 3 The treatments arrangement

\begin{tabular}{lll}
\hline Treatment & $\mathbf{N a C l}$ concentrations $(\mathbf{m M})$ & GB concentrations $(\mathbf{m M})$ \\
\hline $\mathrm{CK}$ & 0 & 0 \\
$\mathrm{~T} 1$ & 150 & 2.5 \\
$\mathrm{~T} 2$ & 150 & 5 \\
$\mathrm{~T} 3$ & 150 & 7.5 \\
$\mathrm{~T} 4$ & 150 & 0 \\
\hline
\end{tabular}

Note: $\mathrm{CK}=$ control; $\mathrm{T} 1=2.5 \mathrm{mM} \mathrm{GB} ; \mathrm{T} 2=5 \mathrm{mM} \mathrm{GB} ; \mathrm{T} 3=7.5 \mathrm{mM} \mathrm{GB}$ and $\mathrm{T} 4=150 \mathrm{mM} \mathrm{NaCl}$

seedlings were irrigated with half-strength Hoagland solution on a regular basis for 20 days after transplantation to provide seedlings the required nutrients for plant growth. On the 20th day of their growth, plants were watered with $\mathrm{NaCl}$ contained in Hoagland solution at $50 \mathrm{mM}$, then watered with $\mathrm{NaCl}$ contained in Hoagland solution at $100 \mathrm{mM}$ on the 22nd day, and the desired salinity level of $150 \mathrm{mM}$ was applied on the 25th day. The salt concertation of $150 \mathrm{mM}$ was maintained until 10 days, and exogenous glycine betaine dissolved in deionized water was daily sprayed on the upper sides of all leaves at $5 \mathrm{ml}$ per plant during those 10 days. A total number of 30 plants was used during the experiment, with 6 plants per treatment. The treatments (Table 3) were laid in a completely randomized design. Photosynthetic, plant growth, and development and chlorophyll fluorescence parameters were periodically measured on the tenth day of double treatments (exogenous GB and salinity). Plants were harvested 10 days after initially being treated with exogenous $\mathrm{GB}$, to measure other physiological and biochemical characteristics as described below.

\section{Gas exchange and chlorophyll fluorescence}

The leaf gas exchange parameters including photosynthetic rate $\left(P_{n}\right)$, intracellular carbon dioxide concentration $\left(C_{i}\right)$, transpiration rate $\left(T_{r}\right)$ and stomatal conductance $\left(g_{s}\right)$ were measured every 3 days from 09: $00 \mathrm{am}$ to 11:00 am BST in all treatments using the tird fully expanded leaves, during the period of exogenous GB application with the Li-6400XT portable photosynthesis system (Li-COR Inc., Lincoln, NE, USA). A single leaf was used per replication for gas exchang measurements. During measurements, reference $\mathrm{CO}_{2}$ concentration was equilibrated to $400 \mu \mathrm{mol} \mathrm{mol}^{-1}$ with a $\mathrm{CO}_{2}$ mixture, and the light adjusted at a PAR of $1200 \mu \mathrm{mol}$ $\mathrm{m}^{-2} \mathrm{~s}^{-2}$. The block temperature was fixed at $25^{\circ} \mathrm{C}$, the leaf-to-air VPD was equilibrated between 1.5 and 2.0 $\mathrm{kPa}$, and the flow was fixed at $300 \mu \mathrm{mol} \mathrm{s}^{-1}$.

Chlorophyll fluorescence was simultaneously measured the same days as measuring leaf gas exchange parameters using the MINI-PAM-II/R Photosynthesis Yield Analyzer. The leaves were adapted to darkness over-night to measure the initial and maximum fluorescence, $\left(F_{o}\right)$ and $\left(F_{m}\right)$ respectively, the variable chlorophyll $\left(F_{v}\right)$ was computed as $F_{v}=F_{m}-F_{o}$ and the maximal photochemical efficiency of photosystem II (PSII) was expressed as $F_{v} / F_{m} . \quad F_{m}^{\prime}$ was measured under the full light, while $F_{o}^{\prime}$ was measured after turning off the light, and $\Delta F$ is the difference between $F_{m}$ and $F_{s}$. The variable chlorophyll fluorescence under the fluorescence condition $\left(F_{v}^{\prime}\right)$ was computed as $F_{v}^{\prime}=F_{m}^{\prime}-F_{o}^{\prime} \cdot q P, q N$ and $N P Q$ were computed as $q P=1-\left(F_{m}^{\prime}-\mathrm{F}\right) /\left(F_{m}^{\prime}-F_{o}^{\prime}\right)$; $q N=1-\left(F_{m}^{\prime}-F_{o}^{\prime}\right) /\left(F_{m}-F_{o}\right)$ and $N P Q=\left(F_{m}-F_{m}^{\prime}\right) /$ $F_{m}^{\prime}$ respectively [50]. The actual photochemical efficiency of Photosystem II $\left(\Phi_{P S I I}\right)$ was computed as:

$$
\Phi_{P S I I}=\frac{F^{\cdot} m-F s}{F^{6} m}
$$

\section{Determination of leaf stomata structure and characteristics}

FEI Scanning Electron Microscope Quanta 200F (Field Emission Instruments Co.) was used to captured Images of the abaxial and adaxial epidermal surface of cotton leaves. Pictures were taken under the $10 x$ eyepiece of the OLYMPUS microscope for stomatal structure and 40x eyepiece for stomatal characteristics [51]. ImageJ 1.4 .8 software was used for processing and analysis.

\section{Determination of plant growth parameters}

Plant growth parameters such as the leaf area and LWP were measured three times in 5 day intervals during the $150 \mathrm{mM}$ salinity stressing period (20-35 DAT). The leaf area was measured using a leaf area meter (model 3050A, Li-Cor Biosciences, Lincoln, NE, USA). The LWP was measured using WP4C, Dewpoint Potential Metter [52].

\section{Quantification of protein, GB, proline and soluble sugar}

Protein content was measured by homogenizing $3 \mathrm{~g}$ of frozen leaf sample in $15 \mathrm{~mL}$ of ice-cold solution containing $100 \mathrm{mM}$ Tris ( $\mathrm{pH} 7.0), 10 \mathrm{mM}$ D-isoascorbic acid, $20 \mathrm{~g} \mathrm{~L}-1$ PVP-10 (polyvinylpyrrolidone), $1.5 \mathrm{~g}$ insoluble PVP, $0.1 \mathrm{mM}$ EDTA, and $2 \mathrm{~mL} \mathrm{~L}^{-1}$ Triton X-100 (Rohm \& Haas Co., Philadelphia, PA) [53]. The homogenized sample was then filtrated with miracloth, and the extract centrifuged at $10000 \mathrm{~g}$ for $15 \mathrm{~min}$ at $4{ }^{\circ} \mathrm{C}$. The supernatant was then loaded in $9.5 \mathrm{~mm}$ dialysis tube packed in sucrose crystals, and stored at $4{ }^{\circ} \mathrm{C}$ until the volume decreased to about 1 to $2 \mathrm{~mL}$. One milliliter of the decreased extract was centrifuge-desalted through a $10 \mathrm{~mL}$ bed of Sephadex G50-300 at $1500 \mathrm{~g}$ for $3 \mathrm{~min}$ to reject component, which molecular weights are less than 15 , 000 [54]. A part of the eluent was analyzed immediately 
for catalase activity, then the remaining stored at $-70^{\circ} \mathrm{C}$ for analysis of total protein content. GB was extracted from $1 \frac{1}{2} \mathrm{~g}$ of frozen tissue using methanol-chloroformwater, and the isolation followed the ion-exchange chromatography procedure described earlier [55]. The instrumentation was as described by A Hanson and D Gage [56]. Proline was determined spectrophotometrically following the ninhydrin method described by LS Bates, RP Waldren and ID Teare [57] using Merck proline as a standard. The soluble sugar content was determined according to Yoon et al. [58] with the following modifications. Approximately $0.1 \mathrm{~g}$ of the sample was weighed, placed in a polypropylene tube containing $6 \mathrm{ml}$ of extraction solution ( $80 \%$ ethanol), homogenized, incubated in a water bath at $65 \mathrm{C}$ for $20 \mathrm{~min}$ and then centrifuged at $3500 \mathrm{rpm}$ for $10 \mathrm{~min}$, after which the supernatant was collected.

\section{Statistical analysis}

One-way ANOVA was done with all data performed as mean $(n=3)$ followed by standard deviation. Significant means were separated using Duncan's test at $p<.05$ in SPSS software of International Business Machine 19.0 (IBM SPSS, Inc., Chicago, IL, U.S.A.). Correlation analysis was performed to determine the associations between measured parameters.

\section{Abbreviations}

BST: Beijing standard time; $\mathrm{C}_{\mathrm{i}}$ : Intracellular $\mathrm{CO}_{2}$ concentration; F: Fluorescence in the steady-state; $\mathrm{F}_{\mathrm{m}}$ : Maximum fluorescence yield; $\mathrm{F}_{\mathrm{o}}$ : Initial fluorescence yield; $F_{s}$ : Steady-state fluorescence; $F_{v}$ : Variable chlorophyll; $F_{v}^{\prime}$ : Variable chlorophyll fluorescence under the fluorescence condition; GB: Glycine betaine; $g_{s}:$ Stomatal conductance; LA: Leaf area; LWP: Leaf water potential; NPQ: Non-photochemical quenching; $P_{n}$ : Photosynthetic rate; qP: Photochemical quenching; qN: Non-photochemical quenching of variable chlorophyll; SD: Stomatal dendity; SL: Stomatal length; SW: Stomatal width; $T_{r}$ : Transpiration rate

\section{Acknowledgments}

We would like to thank our colleagues in the laboratory, the manager of the Key Laboratory of Crop Water Use and Regulation, at the Ministry of Agriculture and Rural Affairs, Xinxiang, Henan, and the China Scholarship Council (CSC).

\section{Authors' contributions}

Conceptualization and design, GY and SX; methodology, SX and GW; software, $\mathrm{AKMH}, \mathrm{MZ}$ and $\mathrm{ASA}$; data collection, $\mathrm{AKMH}, \mathrm{SL}$ and JC; initial original draft preparation, AKMH, SL and GY; and funding acquisition, GY. The author(s) read and approved the final manuscript.

\section{Funding}

This research was supported by the Major Program of the National Natural Science Foundation of China (No. 51790534), the National Natural Science Foundation of China (No. 51879267), the National Key Research and Development Program of China (No. 2017YFC0403303) and the Agricultural Science and Technology Innovation Program (ASTIP), Chinese Academy of Agricultural Sciences. The funding agencies provided the financial support to this study, including experimental implementation, data analysis and the publication fee.

\section{Availability of data and materials}

The datasets used and/or analysed during the current study are available from the corresponding author on reasonable request.

\section{Declarations}

Ethics approval and consent to participate

Not applicable.

\section{Consent for publication}

Not applicable.

\section{Competing interests}

The authors declare that they have no competing interests.

\section{Author details}

${ }^{1}$ Farmland Irrigation Research Institute, Chinese Academy of Agriculture Sciences/Key Laboratory of Crop Water Use and Regulation, Ministry of Agriculture and Rural Affairs, Xinxiang, Henan 453002, People's Republic of China. ${ }^{2}$ Graduate School of Chinese Academy of Agricultural Sciences, Beijing 100081, People's Republic of China.

Received: 6 December 2020 Accepted: 5 February 2021

Published online: 20 March 2021

\section{References}

1. Ahmad P, Alyemeni M, Ahanger M, Egamberdieva D, Wijaya L, Alam P. Salicylic acid (SA) induced alterations in growth, biochemical attributes and antioxidant enzyme activity in faba bean (Vicia faba L.) seedlings under $\mathrm{NaCl}$ toxicity. Russ J Plant Physiol. 2018;65(1):104-14.

2. Wang W, Vinocur B, Altman A. Plant responses to drought, salinity and extreme temperatures: towards genetic engineering for stress tolerance. Planta. 2003;218(1):1-14.

3. Ahmad P, Abdel Latef AA, Hashem A, Abd_Allah EF, Gucel S, Tran L-SP. Nitric oxide mitigates salt stress by regulating levels of osmolytes and antioxidant enzymes in chickpea. Front Plant Sci 2016;7:347.

4. Hamouda I, Badri M, Mejri M, Cruz C, Siddique K, Hessini K. Salt tolerance of $B$ eta macrocarpa is associated with efficient osmotic adjustment and increased apoplastic water content. Plant Biol. 2016;18(3):369-75.

5. Sandhu D, Cornacchione MV, Ferreira JFS, Suarez DL. Variable salinity responses of 12 alfalfa genotypes and comparative expression analyses of salt-response genes. Sci Rep. 2017;7(1):42958.

6. Galvan-Ampudia CS, Testerink C. Salt stress signals shape the plant root. Curr Opin Plant Biol. 2011;14(3):296-302.

7. Hoque MA, Banu MNA, Okuma E, Amako K, Nakamura Y, Shimoishi Y, Murata Y. Exogenous proline and glycinebetaine increase NaCl-induced ascorbate-glutathione cycle enzyme activities, and proline improves salt tolerance more than glycinebetaine in tobacco bright Yellow-2 suspensioncultured cells. J Plant Physiol. 2007;164(11):1457-68.

8. Hare PD, Cress WA, Van Staden J. Dissecting the roles of osmolyte accumulation during stress. Plant Cell Environ. 1998;21(6):535-53.

9. Sakamoto A, Murata N. Genetic engineering of glycinebetaine synthesis in plants: current status and implications for enhancement of stress tolerance. J Exp Bot. 2000;51(342):81-8.

10. Alasvandyari F, Mahdavi B, Hosseini SM. Glycine betaine affects the antioxidant system and ion accumulation and reduces salinity-induced damage in safflower seedlings. Arch Biol Sci. 2017;69(1):139-47.

11. Kaya C, Sönmez O, Aydemir S, Dikilitaş M. Mitigation effects of glycinebetaine on oxidative stress and some key growth parameters of maize exposed to salt stress. Turk J Agric For. 2013;37(2):188-94.

12. Chen TH, Murata N. Glycinebetaine protects plants against abiotic stress: mechanisms and biotechnological applications. Plant Cell Environ. 2011; $34(1): 1-20$.

13. Sakamoto A, Murata N. The role of glycine betaine in the protection of plants from stress: clues from transgenic plants. Plant Cell Environ. 2002; 25(2):163-71.

14. Adams WW, Muller O, Cohu CM, Demmig-Adams B. May photoinhibition be a consequence, rather than a cause, of limited plant productivity? Photosynth Res. 2013;117(1-3):31-44.

15. Jiang $\mathrm{Q}$, Roche $\mathrm{D}$, Monaco T, Hole D. Stomatal conductance is a key parameter to assess limitations to photosynthesis and growth potential in barley genotypes. Plant Biol. 2006;8(4):515-21.

16. Brugnoli E, Lauteri M. Effects of salinity on stomatal conductance, photosynthetic capacity, and carbon isotope discrimination of salt-tolerant 
(Gossypium hirsutum L.) and salt-sensitive (Phaseolus vulgaris L.) C3 nonhalophytes. Plant Physiol. 1991;95(2):628-35.

17. Pretorius M. Evaluation of irrigated cotton cultivars in South Africa (MSC. Thesis). South Africa: University of the Free State; 2009

18. Hamani AKM, Wang G, Soothar MK, Shen X, Gao Y, Qiu R, Mehmood F. Responses of leaf gas exchange attributes, photosynthetic pigments and antioxidant enzymes in NaCl-stressed cotton (Gossypium hirsutum L.) seedlings to exogenous glycine betaine and salicylic acid. BMC Plant Biol. 2020;20(1):1-14.

19. Ashraf M, Foolad MR. Roles of glycine betaine and proline in improving plant abiotic stress resistance. Environ Exp Bot. 2007;59(2):206-16.

20. Arzani A, Ashraf M. Smart engineering of genetic resources for enhanced salinity tolerance in crop plants. Crit Rev Plant Sci. 2016;35(3):146-89.

21. Lokhande VH, Nikam TD, Penna S. Biochemical, physiological and growth changes in response to salinity in callus cultures of Sesuvium portulacastrum L. Plant Cell Tissue Organ Cult (PCTOC). 2010;102(1):17-25.

22. Semida WM. A novel organo-mineral fertilizer can alleviate negative effects of salinity stress for eggplant production on reclaimed saline calcareous soil. Acta Hortic. 2014:(no. 1034):493-499.

23. Kader MHA, CJea SX. Reduction in photosynthesis of cotton seedling under water and salinity stresses is induced by both Stomatal and non-stomatal limitations. J Irrig Drain. 2020;39(11):13-8.

24. Buckley TN. The control of stomata by water balance. New Phytol. 2005; 168(2):275-92.

25. Chatrath $A$, Mandal P, Anuradha M. Effect of secondary salinization on photosynthesis in fodder oat (Avena sativa L.) genotypes. J Agron Crop Sci. 2000;184(1):13-6.

26. Ball MC, Farquhar GD. Photosynthetic and stomatal responses of two mangrove species, Aegiceras corniculatum and Avicennia marina, to long term salinity and humidity conditions. Plant Physiol. 1984;74(1):1-6.

27. Farquhar $G$, Ball $M$, Von Caemmerer $S$, Roksandic Z. Effect of salinity and humidity on $\delta 13 \mathrm{C}$ value of halophytes-evidence for diffusional isotope fractionation determined by the ratio of intercellular/atmospheric partial pressure of CO 2 under different environmental conditions. Oecologia. 1982; 52(1):121-4

28. Chaves MM, Flexas J, Pinheiro C. Photosynthesis under drought and salt stress: regulation mechanisms from whole plant to cell. Ann Bot. 2009; 103(4):551-60.

29. Acosta-Motos JR, Ortuño MF, Bernal-Vicente A, Diaz-Vivancos P, SanchezBlanco MJ, Hernandez JA. Plant responses to salt stress: adaptive mechanisms. Agronomy. 2017;7(1):18.

30. Maswada HF, Djanaguiraman M, Prasad PW. Response of photosynthetic performance, water relations and osmotic adjustment to salinity acclimation in two wheat cultivars. Acta Physiol Plant. 2018;40(6):105.

31. Mäkelä P, Kontturi M, Pehu E, Somersalo S. Photosynthetic response of drought-and salt-stressed tomato and turnip rape plants to foliar-applied glycinebetaine. Physiol Plant. 1999;105(1):45-50.

32. Yang X. Lu C. photosynthesis is improved by exogenous glycinebetaine in salt-stressed maize plants. Physiol Plant. 2005;124(3):343-52

33. Tahjib-UI-Arif M, Sohag AAM, Afrin S, Bashar KK, Afrin T, Mahamud A, Polash MAS, Hossain M, Sohel M, Taher A. Differential response of sugar beet to long-term mild to severe salinity in a soil-pot culture. Agriculture. 2019; 9(10):223.

34. Abdullah Z, Ahmad R. Effect of pre-and post-kinetin treatments on salt tolerance of different potato cultivars growing on saline soils. J Agron Crop Sci. 1990;165(2-3):94-102.

35. Misra AN, Sahu SM, Misra M, Singh P, Meera I, Das N, Kar M, Sahu P. Sodium chloride induced changes in leaf growth, and pigment and protein contents in two rice cultivars. Biol Plant. 1997:39(2):257-62.

36. Jamil M, Lee K, Kim JM, Kim H-S, Rha ES. Salinity reduced growth PS2 photochemistry and chlorophyll content in radish. Sci Agric. 2007;64(2):111-8.

37. Al-aghabary K, Zhu Z, Shi Q. Influence of silicon supply on chlorophyll content, chlorophyll fluorescence, and antioxidative enzyme activities in tomato plants under salt stress. J Plant Nutr. 2005;27(12):2101-15.

38. Heidari M, Karami V. Effects of different mycorrhiza species on grain yield, nutrient uptake and oil content of sunflower under water stress. J Saudi Soc Agric Sci. 2014;13(1):9-13.

39. Kanwal H, Shahbaz M, Ashraf M. Assessment of salt tolerance of some newly developed and candidate wheat (triticum aestivum I) cultivars using gas exchange and chlorophyll fluorescence attributes. Pak J Bot. 2011:43(6): 2693-9.
40. Wu X, Zhu Z, Li X, Zha D. Effects of cytokinin on photosynthetic gas exchange, chlorophyll fluorescence parameters and antioxidative system in seedlings of eggplant (Solanum melongena L.) under salinity stress. Acta Physiol Plant. 2012;34(6):2105-14.

41. Cheng W, Huang Y, Meng C, Zhang N, Zeng H, Ren J, Li Y, Sun Y. Effect of exogenous 24-epibrassinolide on salt resistance of watermelon (Citrullus lanatus L.) under salinity stress. In: 5th International Conference on Advanced Design and Manufacturing Engineering: Atlantis Press; 2015.

42. Björkman O, Demmig B. Photon yield of O 2 evolution and chlorophyll fluorescence characteristics at $77 \mathrm{~K}$ among vascular plants of diverse origins. Planta. 1987:170(4):489-504.

43. Perveen S, Hussain S. Methionine-induced changes in growth, glycinebetaine, ascorbic ACID, total soluble proteins and anthocyanin contents of two Zea mays L. varieties under salt stress. J Anim Plant Sci. 2021;31(1).

44. Demiral T, Türkan I. Exogenous glycinebetaine affects growth and proline accumulation and retards senescence in two rice cultivars under $\mathrm{NaCl}$ stress. Environ Exp Bot. 2006;56(1):72-9.

45. Raza SH, Athar HR, Ashraf M, Hameed A. Glycinebetaine-induced modulation of antioxidant enzymes activities and ion accumulation in two wheat cultivars differing in salt tolerance. Environ Exp Bot. 2007; 60(3):368-76

46. Sulpice R, Gibon Y, Bouchereau A, Larher F. Exogenously supplied glycine betaine in spinach and rapeseed leaf discs: compatibility or noncompatibility? Plant Cell Environ. 1998;21(12):1285-92.

47. Yildirim E, Ekinci M, Turan M, Dursun A, Kul R, Parlakova F. Roles of glycine betaine in mitigating deleterious effect of salt stress on lettuce (Lactuca sativa L.). Arch Agron Soil Sci. 2015;61(12):1673-89.

48. Gadallah M. Effects of proline and glycinebetaine on Vicia faba responses to salt stress. Biol Plant. 1999;42(2):249-57.

49. Zhang L, Gao M, Zhang L, Li B, Han M, Alva AK, Ashraf M. Role of exogenous glycinebetaine and humic acid in mitigating drought stressinduced adverse effects in Malus robusta seedlings. Turk J Bot. 2013;37(5): 920-9.

50. Liu Z, Chen W, He X. Influence of $\mathrm{cd} 2+$ on growth and chlorophyll fluorescence in a Hyperaccumulator: Lonicera japonica Thunb. J Plant Growth Regul. 2015;34(3):672-6.

51. Pathare VS, Koteyeva N, Cousins AB. Increased adaxial stomatal density is associated with greater mesophyll surface area exposed to intercellular air spaces and mesophyll conductance in diverse C4 grasses. New Phytol. 2020; 225(1):169-82.

52. Wang C, Wu S, Tankari M, Zhang X, Li L, Gong D, Hao W, Zhang Y, Mei X, Wang $Y$. Stomatal aperture rather than nitrogen nutrition determined water use efficiency of tomato plants under nitrogen fertigation. Agric Water Manag. 2018;209:94-101.

53. Foster JG, Hess JL. Responses of superoxide dismutase and glutathione reductase activities in cotton leaf tissue exposed to an atmosphere enriched in oxygen. Plant Physiol. 1980;66(3):482-7.

54. Helmerhorst E, Stokes G. Microcentrifuge desalting: a rapid, quantitative method for desalting small amounts of protein. Anal Biochem. 1980;104(1): 130-5.

55. Hanson AD, Rathinasabapathi B, Chamberlin B, Gage DA. Comparative physiological evidence that $\beta$-alanine betaine and choline-O-sulfate act as compatible osmolytes in halophytic Limonium species. Plant Physiol. 1991; 97(3):1199-205.

56. Hanson A, Gage D. Identification and determination by fast atom bombardment mass spectrometry of the compatible solute choline-Osulfate in Limonium species and other halophytes. Funct Plant Biol. 1991; 18(4):317-27.

57. Bates $L S$, Waldren RP, Teare ID. Rapid determination of free proline for water-stress studies. Plant Soil. 1973:39(1):205-7.

58. Yoon Y-E, Kuppusamy S, Cho KM, Kim PJ, Kwack Y-B, Lee YB. Influence of cold stress on contents of soluble sugars, vitamin $C$ and free amino acids including gamma-aminobutyric acid (GABA) in spinach (Spinacia oleracea). Food Chem. 2017;215:185-92.

\section{Publisher's Note}

Springer Nature remains neutral with regard to jurisdictional claims in published maps and institutional affiliations. 